\title{
DEVELOPMENTAL CHANGES OF TRIMERIC GTP-BINDING PROTEINS IN PORCINE BRAIN AND IMMUNE SYSTEM
}

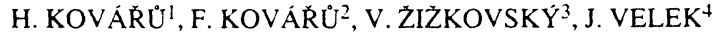 \\ ${ }^{1}$ Research Psychiatric Laboratory, 1 st Medical Faculty, Charles University, Prague, \\ ${ }^{2}$ Department of Physiology, University of Veterinary and Pharmaceutical Sciences, Brno, \\ ${ }^{3}$ State Health Institute, Prague, ${ }^{4}$ Institute of Organic Chemistry and Biochemistry, \\ Academy of Sciences of Czech Republic, Prague, Czech Republic
}

Received January 23, 1998

Accepted March 3, 1998

\begin{abstract}
Kovářủ H., F. Kovářủ, V. Žižkovský, J. Velek: Developmental Changes of Trimeric GTP-binding Protein in Porcine Brain and Immune System. Acta vet. Brno 1998, 67: 15-20.

We studied developmental changes of membrane trimeric alpha subunits of GTP-binding proteins ( $\mathrm{G}$ proteins), i.e. $\mathrm{G}$ alpha $(\mathrm{q} / 11), \mathrm{G}$ alpha $(\mathrm{s})$ and $\mathrm{G}$ alpha $(\mathrm{i} 1,2)$ in porcine brain cortex, thymus and spleen on fetal day 92 (FD 92) and 110 (FD 110, newborn), postnatal day 60 (PD 60), and in adult animals. We used immunochemical techniques ELISA or Western blotting with rabbit antibodies against synthetic $\mathrm{C}$-terminal dekapeptides of $\mathrm{G}$ alpha subunits prepared by us. In control tests no cross reactivity of $G$ alpha-antisera was detected by ELISA method. Brain cortex was characterized by age-dependent marked decline of $G$ alpha $(q / 11)$ and slight decrease of both $\mathrm{G}$ alpha (s) and $\mathrm{G}$ alpha (i1,2). In thymus, higher levels of $\mathrm{G}$ alpha $(\mathrm{q} / 11)$ were estimated on FD 92 which was similar to those on FD 110 and in both thymus and spleen $G$ alpha (s) increased with age. We observed age-induced elevation of $\mathrm{G}$ alpha $(\mathrm{il}, 2)$ subunit in thymus, whereas spleen $\mathrm{G}$ alpha ( il,2) levels were similar. When summarized, opposite courses of developmental levels of $\mathrm{G}$ alpha subunits in brain cortex and lymphoid organs were demonstrated, i.e. brain-dependent decrease and lymphoid tissue-dependent increase as a function of age. These data can represent molecular changes and tissue specifities of differentiation and maturation in the porcine organism.
\end{abstract}

Thymus, spleen, G-alpha subunit, G protein

A prerequisite for the maintenance of homeostasis in a living organism is fine-tuned communication between different cells and systems. The majority of extracellular signalling molecules, such as hormones, neurotransmitters and cytokines, interact with three-protein transmembrane signalling system consisting of a receptor, a GTP-binding protein (G protein), and an effector (Guderman et al. 1997). Molecular cloning studies have shown that $\mathrm{G}$ protein-coupled receptors form one of the largest protein families found in nature and it is estimated that approximately 1000 different receptors exist in mammals (Wess 1997). They are coupled with limited repertoire of $G$ proteins and interact with a few effector molecules that include adenylylcyclases, cyclic -GMP phosphodiesterases, phospholipase $\mathrm{C}$ and various ion channels (Malbon 1997). Heterotrimeric G proteins with intrinsic GTPase activity are composed of 3 subunits, i.e. functionally highly important alpha subunit operating with betagamma subunits (Millig an 1988). G proteins are divided into main groups according to their effector effects: $G(s)$, and $G(i)$ regulate adenylylcyclase, $G(q)$ operates via phospholipase $\mathrm{C}$ and $\mathrm{G}(\mathrm{o})$ is related to ion channels, and in many events the effects of $\mathrm{G}$ proteins are combined (Milligan et al. 1996; Guderman 1997). Dramatic changes in specific $G$ protein subunits that coincide with committment to highly specialized cell types suggest a key role for these 
extrinsic membrane proteins in molecular switches in the complex biological processes controlling both cellular differentiation and development during phylogenesis from insects to mammals, including the nervous system (Copenhaver et al. 1995). Thus the G proteins can regulate early stages of neurogenesis, providing a mechanism for the epigenetic control of neuronal differentiation from mouse embryonic stem cells (Strubing et al. 1997). Changes in the immune system were analyzed using human thymocytes, and investigation of their $\mathrm{G}$ alpha subunit diversity indicate presence $\mathrm{G}$ alpha (i1-3) and $\mathrm{G}$ alpha( $\mathrm{z}$ ) but not $\mathrm{G}$ alpha (o), $\mathrm{G}$ alpha (s) and $\mathrm{G}$ alpha(q) (Kabouridis et al. 1995). On the other hand, $\mathrm{G}$ alpha $\mathrm{q} / 16$ is restricted to progenitor B cells during B lymphocyte differentiation (Mapara et al. 1995). $\mathrm{T}$ lymphocyte activation with engagement of $\mathrm{T}$ cell receptor-CD3 complex is modulated by $\mathrm{G}$ alpha q/11 family (Stanners et al. 1995). Changes in G alpha subunits of C-6 glioma cells and natural killer lymphocytes were investigated (Kov ář e et al. 1995. $1997 \mathrm{ab}$ ).

We analyzed developmental levels of $\mathrm{G}$ alpha (Gs, Gi1,2, Gq/11) subunits in pig brain and lymphoid organs thymus and spleen. The study can extend our knowledge about dynamic changes of $\mathrm{G}$ alpha subunits linked to proliferation, maturation and differentiation events. Studies in prenatal period of the pig are immunologically important with respect to spontaneous development of the immune system without antigen effects because of impermeability of porcine placenta to immunoglobulins (Kovář e̊ et al. 1995). A preliminary report was presented earlier (Kovářů et al. 1996).

\section{Materials and Methods}

\section{Experimental animals}

We used fetuses and piglets ( 8 for each age studied) of Czech Large White breed from three litters. Optimal halothan-oxygen- $\mathrm{N}_{2} \mathrm{O}$ anaesthesia was used during experimental hysterotomy and other experimental procedures (Kovář ú et al. 1971 and 1996). After birth, the piglets were reared under physiological conditions and fed maternal milk. From d 5 to $\mathrm{d} 30, C^{\circ} O S-1$ commercial diet was available to them ad libitum. On d 30 (weaning time), a stepwise change to COS- 2 commercial diet was performed and this diet was fed until d 60 . Care of the experimental animals was provided according to recommendation of FELASA and European Community. Samples of brain cortex, thymus and spleen were collected and immediately frozen at $-80^{\circ} \mathrm{C}$.

\section{Preparation of crude membranes}

Fragments of tissue were homogenised in $50 \mathrm{mM}$ Tris- $\mathrm{HCl} \mathrm{pH} \mathrm{7.4,} \mathrm{containing} \mathrm{proteolytic} \mathrm{inhibitors}-0.1 \mathrm{mM}$ benzamidine, $0.3 \mathrm{mM}$ PMSF (phenyl-methylsulphonyl fluoride), $1 \mathrm{mM}$ DTT (dithiothreitol) and $1 \mathrm{mM}$ EDTA and centrifuged at $1000 \mathrm{~g}$ for $10 \mathrm{~min}$ at $4{ }^{\circ} \mathrm{C}$. Resulting supernatant was then centrifuged at $40,000 \mathrm{~g}$ for $20 \mathrm{~min}$ at 4 ${ }^{\circ} \mathrm{C}$ and membrane protein extracted for $1 \mathrm{~h}$ at $4{ }^{\circ} \mathrm{C}$ in $20 \mathrm{mM}$ Tris- $\mathrm{HCl} \mathrm{pH} 8.0$ containing $25 \mathrm{mM} \mathrm{NaCl}, 1 \mathrm{mM}$ EDTA and $1 \%$ sodium cholate. Extract was centrifuged at $100,000 \mathrm{~g}$ for $1 \mathrm{~h}$ at $4{ }^{\circ} \mathrm{C}$ and supernatant utilized for assays of $\mathrm{G}$ alpha subunits; for other details Lesch and Manji (1992).

\section{$G$ alpha subunit estimation}

$\mathrm{G}$ alpha changes in cholate membrane extracts were analyzed by ELISA technique with our rabbit antibodies against synthetic C-terminal dekapeptides of alpha chains of Gs, Gi1,2 and Gq/11 (Goldsmith et al. 1987; Milligan 1988; Kovářủ et al. 1995). No cross reaction between our $G$ alpha-antisera and initial peptides for immunization was detected. ELISA method of competitive inhibiton was performed (Ransnas and Insel 1989; Lesch and Manji 1992) and was modified by us with use of Maxisorp microtitration plates (NUNC) for noncovalent peptide binding. Immunochemical staining with horse radish peroxidase conjugate with goat antirabbit IgG with o-phenylendiamine as substrate or alkaline phosphatase conjugate with goat antirabbit $\operatorname{lgG}$ and p-nitrophenyl-phosphate as substrate was used (Tijssen 1993; Kováŕủ et al. 1997b). The results were confirmed by Western immunoblotting. Cholate extracts were fractionated by SDS polyacrylamide gel electrophoresis with subsequent electrotransfer to Protran nitrocellulose sheet using semidry transfer system Carboglass (Schleider Schuell). After washing, blocking blots with BSA in PBS, and first antibody staining, immunocytochemical staining by horse-radish peroxidase conjugate with goat antirabbit $\operatorname{lgG}$ with o-dianisine- $\mathrm{HCl}$ (Sigma, USA) was performed (Milligan 1988; Lesch and Manji 1992; Tijssen 1993).

\section{Statistical analysis}

The data are expressed as mean values + S.D. The differences between experimental samples were evaluated by Student's t-test for unpaired values. 


\section{Results and Discussion}

We compared $G$ alpha subunits in early postnatal period of piglets with those found at the fetal ages under study. Fetuses FD 92 and FD 110 were obtained by hysterotomy. Piglets FD 110 were used as newborns (their organ systems are fully functionally and morphologically developed; therefore e.g. in gnotobiology they are routinely used as germ-free animals).

We studied changes of $G$ alpha subunit levels in brain cortex (Fig.1) which can be characterized as agedependent high decrease of $\mathrm{G}$ alpha ( $\mathrm{q} / 11$ ) (FD 92 vs PD $60 \mathrm{p}<0.05$ ), and slight decrease of $G$ alpha (s) and $\mathrm{G}$ alpha (i1,2) subunits. Changes in $G$ alpha subunits were confirmed by Western immunoblotting. Demonstrated $\mathrm{G}$ alpha subunit patterns during both final fetal and early postnatal pig life are in agreement with higher degree of central nervous system maturation at this period in contrast to the opposite state in the rat. Rat postnatal development is accompanied with increased $\mathrm{G}$ alpha (o) and (q) subunits in brain until 3 months reflecting maturation changes, whereas $G$ alpha (i2) remained relatively constant throughout maturation (Miyamoto and Ohshika 1993). We observed that $\mathrm{G}$ alpha (o) level was higher by $30 \%$ in brain cortex in comparison with spleen or thymus on day FD 110 (data not shown). G (o) protein is abundant in brain (Strubing et al. 1997) but our results indicate that newborn pig spleen or thymus is able to express certain levels of $G$ alpha (o) subunit. Distributions of $G$ alpha subunits (Go, Gs, Gil 2 ) in various rat brain cortex regions were estimated in pmoles per $\mathrm{mg}$ protein: $G$ alpha (o) was the most abundant (approximately 40-90), $\mathrm{G}$ alpha (i 1,2) (approximately 25-40), and G alpha (s) (approximately 5-15), (Lesch and Manji 1992). Similar values are not known for lymphoid tissues.

We studied changes in $G$ alpha subunit expression in thymus and spleen on fetal day (FD) 92 and 110 and

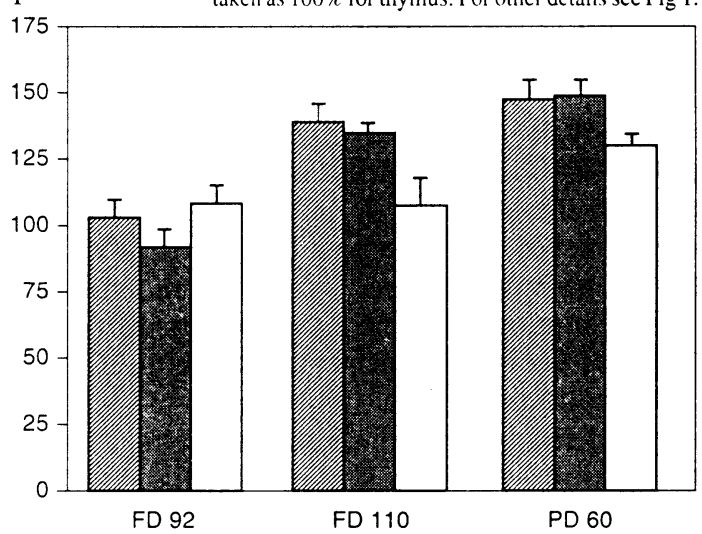
D 92

FD 110

PD 60 es of $\mathrm{G}$ alpha subunits in pig brain cortex

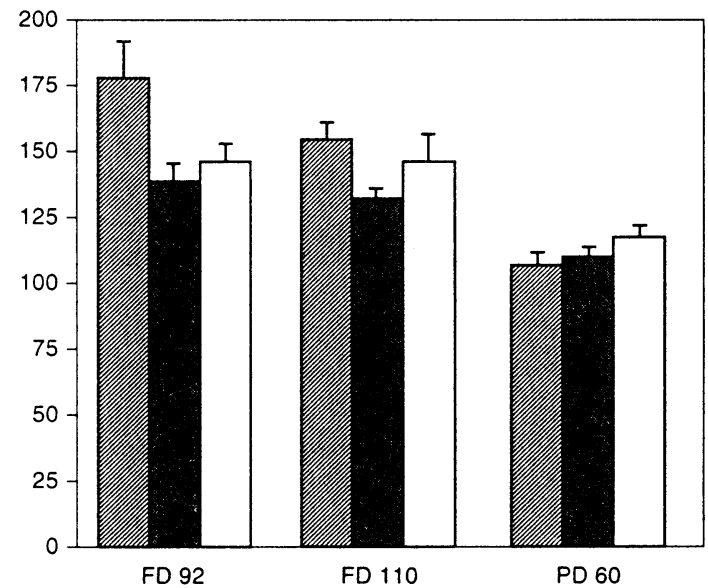

Fetal days 92,110 and postnatal day 60 are marked as FD 92 . FD 110 and PD 60 , respectively. Values in adults were taken as $100 \%$. Full columns indicate $\mathrm{G}$ alpha $(\mathrm{q} / 11)$, hatched columns demonstrate $\mathrm{G}$ alpha (s) and open columns show $\mathrm{G}$ alpha (i1,2).

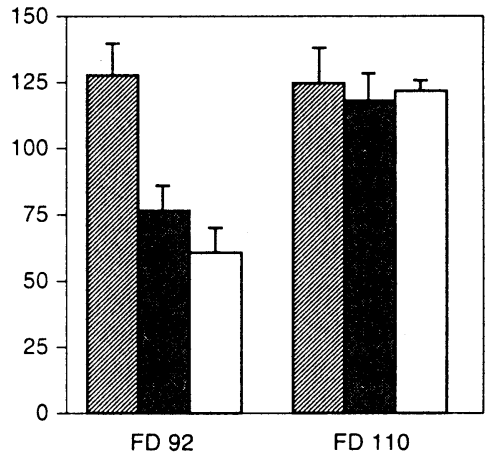

Fig. 2. Developmental changes of $\mathrm{G}$ alpha subunits in pig thymus (2a 1$)$ and spleen ( $2 \mathrm{~b} \backsim)$. PD 60 values were
taken as $100 \%$ for thymus. For other details see Fig 1. 
postnatal day 60. In thymus (Fig 2a), both FD 92 and FD 100 intervals were characterized by similarly high $\mathrm{G}$ alpha (q/11). On FD 110 , both $\mathrm{G}$ alpha (s) and $\mathrm{G}$ alpha (i1,2) subunits were significantly increased $(\mathrm{p}<0.05)$ in comparison with FD 92. It is important, that fetal, newborn and early postnatal pig thymus can be characterized by $\mathrm{G}$ alpha (q/11) subunit as confirmed also by Western immunoblotting (data not shown). On the other hand, changes in the immune system were analyzed using human thymocytes. They indicate presence of G alpha (i1-3) and G alpha (z) but not G alpha (o), G alpha (s) and G alpha (q) (Kabourid is et al. 1995).

In the spleen (Fig 2b), FD 92 was characterized with lower $G$ alpha ( $q / 11)$ and (s) subunit expressions, followed by their significant increases on FD 110 and PD 60 ( $G$ alpha q/11, PD 60 vs FD 92 p= 0.05) and G alpha s (FD 110 vs FD $92 p<0.05$, PD 60 vs FD $92 p=0.01$ ).

Expression of spleen $\mathrm{G}$ alpha (i 1,2) was relatively similar during FD 92 and FD 110 followed by a slight but non-significant increase on PD 60. In general, in thymus and spleen we demonstrated an age-dependent increase in expression of $\mathrm{G}$ alpha subunits. It is evident, that the development of porcine thymus is linked to $G$ alpha (s) and $\mathrm{G}$ alpha (i1,2) subunits with similarly higher $\mathrm{G}$ alpha $(\mathrm{q} / 11)$, whereas spleen changes are $G$ alpha (q/11)- and $G$ alpha (s)-dependent with a slight increase $G$ alpha (i1,2). Markedly increased thymus $\mathrm{G}$ alpha (s) and $\mathrm{G}$ alpha ( $\mathrm{q} / 11$ ) can be linked to intensive maturation and differentiation in thymus as primary lymphoid organ, and the relationship of these $\mathrm{G}$ proteins to regulation of $\mathrm{T}$ cell receptor-CD3 was described (Haack et al. 1993; St anners et al.1995). Spleen as a secondary lymphoid organ, with developmental $\mathrm{G}$ alpha subunit differences, including $\mathrm{G}$ alpha $(\mathrm{q} / 11)$ could be a part of maturation and differentiation mechanisms as also observed in differentiated human B cells accompanied by $G$ alpha ( $q / 16$ ) changes (Mapara et al. 1997). Differences in $\mathrm{G}$ alpha subunit expressions in the early postnatal period (PD 60) as compared to newborn pigles, were not markedly significant in the spleen from the point of view of changes of entire cell populations in this lymphoid organ at a time when extramedullary hemopoiesis ceases, and an increase of immunologically active cells ( $\mathrm{T}$ and $\mathrm{B}$ lymphocytes, dentritic macrophages etc.) is evident. Estimation of individual contributions the these immunocompetent cells to changes in the entire splenocyte population would require experiments with isolated subpopulations. In spite of the different profiles of thymus and spleen, $\mathrm{G}$ alpha subunit can reflect $\mathrm{T}$ - B cell dichotomy mechanisms (Kovářủ et al. 1995).

\section{Vývojové změny trimerních GTP-vazebných proteinů v prasečím mozku a imunitním systému}

Studovali jsme změny membránových trimerních alfa-subjednotek GTP-vazebných proteinů, ( $G$ proteinů), t.j. $G$ alfa ( $($ /11), $G$ alfa (s) a $G$ alfa ( il,2) v prasečím mozkovém kortexu, thymu a slezině během fetálního období ( FD 92 a FD 110, novorozené), časného postnatálního života (PD 60) a dospělosti .Pro stanovení hladin Galfa subjednotek jsme využili imunochemické techniky, převážně ELISA (enzymelinked immunosorbent assay) a rovněž imunoblotování (Western immunoblotting). Pro tyto účely jsme připravili antikráličí protilátky proti syntetickým C-terminálním dekapeptidům $G$ alfa subjednotek př́slušných $G(q / 11), G(s)$ a $G(i 1,2)$ proteinů. Žádná křížová reakce mezi získanými anti-G alfa antisery nebyla zjištěna ELISA technikou. Mozkový kortex byl charakterizován výrazným poklesem G alfa (q/11) a méně výrazným snižením $G$ alfa (s) a $G$ alfa $(i 1,2)$ v ontogenetických intervalech. 
$\mathrm{V}$ thymu jsme nalezli vyšší hodnoty $\mathrm{G}$ alfa $(\mathrm{q} / 11)$, které byly podobné $v$ intervalu $F D$ 92 a FD 110, kdežto na věku závislé zvýšení G alfa (s) bylo zjištěno v thymu i slezině. Vývojové změny $G$ alfa $(i 1,2)$ subjednotky byly prokázány jako zvýšení v thymu, kdežto ve slezině byly hladiny této $G$ alfa subjednotky podobné. Výsledky lze obecně shrnout tak, že jsme prokázali opačné vývojové průběhy změn $G$ alfa subjednotek v mozkovém kortexu a lymfoidních orgánech, což představuje na věku závislé snížení hladin $G$ alfa subjednotek $v$ mozkové kưře a zvýšení $G$ alfa subjednotek $v$ thymu a slezině. Tyto údaje představují molekulární změny a tkáňové specificity diferenciace a maturace $v$ prasečím organismu.

\section{Acknowledgements}

The authors thank for technical assistance to Mrs. E. Richterová and Mr Z. Hanuš and for help with manuscript preparation to Dr. Z. Fišr. Supported by grant 309/95/ 1121 (Grant Agency of Czech Republic) and grant 143/ 97 ( Grant Agency of Charles University).

\section{References}

COPENHAVER, P. F., HORGAN, A. M., NICHOLS, D. C., RASMUSSEN M. A. 1997: Developmental expression of heterotrimeric $G$ proteins in the nervous system of Manduca sexta. J. Neurobiol. 26: 461-484

GOLDSMITH, P., GIERSCHIK, P., MILLIGAN, G., UNSON, C.G., VINITSKY, R., MALECH, H. L., SPIEGEL, A. M. 1987: Antibodies directed against synthetic peptides distinguish between GTP- binding proteins in neutrophil and brain. J. Biol. Chem. 262: 14683-14688

GUDERMANN, T., SCHONEBERG, SCHULTZ, G. 1997: Functional and structural complexity of signal transduction via G-protein-coupled receptors. Ann. Rev. Neurosci. 20: 399-427

HAACK, B. M., EMMRICH, F., RESCH, K. 1993: Cholera toxin inhibits T cell receptor signaling by covalent modification of CD3 subunit. J. Immunol. 150: 2599-2606

KABOURIDIS, P. S., WATERS, S. T., ESCOBAR, S., STANNERS, J., TSOUKAS, C.D. 1995: Expression of GTP-binding protein alpha subunits in human thymocytes. Mol. Cell. Biochem. 144: 45-51

KOVÁŘŮ, F., STOŽICKÝ, V., KRUML, J., DLABAĆ V., DONÁT, J., NOVOTNÁ, J. 1971: Experimental surgery in the fetal period of mammals. Acta vet. Brno 40, Suppl. 3: 1-68

KOVÁR̆Ů, F., KOVÁR̆Ů, H. 1996: Pig in biomedical research. Abstract, VIth FELASA Symposium, June 19-21, Basel, Switzerland: p. 72

KOVÁR̆Ů, F., KOVÁŔ̛̛, H., HALOUZKA, R., ŚPANOVÁ A., PALÍKOVÁ S., DRÁBEK J. 1995: Ontogenetic changes in immunophenotypic markers on pig lymphocytes. Royal Micr. Soc. 30, Pt 2: 122-123

KOVÁR̉U, H., LISÁ, V., FIŠAR, Z., KOVÅRƯ, F., ČRNÁ, V., ŽIŽKOVSKÝ, V., DOBROVSKÝ K. 1995: Antidepressant effects on expression of $\mathrm{G}$ alpha subunits in C-6 glioma cells. Royal Micr. Soc. 30, Pt 2: 123

KOVÁŔ̊̊. H., KOVÁR̃Ů, F., FIŠAR, Z., SVOBODA, P., MALBOHAN, I., ŽIŽKOVSKÝ, V. 1996: Development of $G$ alpha subunits in pig immune system. Proc. 14th Int. IPVS Congress. Bologna, Italy: 380

KOVÁŘŨ, H., FIŠEROVÁ, A., LISÁ, V., ŠPANOVÁ, A., KOVÁR̉Ũ, F., VELEK, J. 1997a: Fluoxetine induced changes in C-6 glioma cells and NK lymphocytes. In: Biological Basis of Psychiatric Disorders, (Eds. J. Sikora, Z. Fišar, P. Petrovický R. Jirák), Galén. Praha: 108-112

KOVÁŘ́, H., FIŠEROVÁ. A., LISÁ, V., , KOVÁŘŮ, F., FIŠAR, Z., MALBOHAN, I. 1997b: Antidepressant effects on GTP-binding proteins in C-6 glioma cells and natural killer lymphocytes. Biol. Psychiat. 42/ IS: $47 \mathrm{~S}$

LESCH, K. P., MANJI, H. K. 1992: Signal transducing G proteins and antidepressant drugs: evidence for modulation of alpha subunit gene expression in rat brain. Biol. Psychiat. 32: 549-579

MALBON, C. C. 1997: Heterotrimeric G-proteins and development. Biochem. Pharmacol. 53: 1-4

MAPARA. M. Y.. BOMMERT, K., BARGOU, R. C., LENG, C., LUDWIG, W. D. GIERSCHIK, P., DORKEN, B. 1995: $G$ protein subunit $g$ alpha 16 expression is restricted to progenitor B cells during human B cell differentiation. Blood 85: 1836-1842

MILLIGAN, G. 1988: Techniques used in the identification and analysis of function of pertussis toxin-sensitive guanine nucleotide binding proteins. Biochem. J. 255: 1-13

MILLIGAN. G., MARSHAL.L, F., REES, S. 1996: G 16 as universal G protein adapter: implications for agonist screening strategies. TIPS 17: 235-237

MIYAMOTO, A., OHSHIKA H. 1993: Developmental changes in G proteins expression in rat cerebral cortex. J. Neurochem. 61, Suppl.: S 106 
RANSNAS, L. A., INSEL, P. A. 1989: Quantitation of a guanine nucleotide binding regulatory protein by an enzyme-linked immunosorbent competition assay. Anal. Biochem. 176: 185-190

STANNERS, J., KABOURIDIS, P. S., MCGUIRE, K. L., TSOUKAS, C. D. 1995: Interaction between G proteins and tyrosine kinases upon T cell receptor-CD3-mediated signaling. J. Biol. Chem. 270: 30635-30642

STRUBING, C., ROHWEDEL, J., AHNERTHILGER, G., WIEDENMANN, B., HESCHELER, J., WOBUS, A. M. 1997: Development of $\mathrm{G}$ protein-mediated $\mathrm{Ca}^{2+}$ channel regulation in mouse embryonic stem cell-derived neurons. Eur. J. Neurosci. 9: 824-832

TIJSSEN, P. 1993: Quantitative enzyme immunoassay techniques. In: Practice and theory of enzyme immunoassays, (Ed. P.Tijssen) Elsevier, Amsterdam, London, N,York, Tokyo, pp. 329-447

WESS, J. 1997: G-protein-coupled receptors: molecular mechanisms involved in receptor activation and selectivity of G-protein recognition. FASEB Journal 11: 346-354 